\title{
Utilization of Iraqi Metakaolin in Special Types of Concrete: A Review Based on National Researches
}

\author{
Mahmood Fawzi Ahmed \\ Lecturer Dr. \\ Department Education of Hit \\ General Directorate of Education in Anbar \\ Anbar, Iraq \\ mahmodmfa81@gmail.com
}

\begin{abstract}
Portland cement concrete is the most commonly used construction material in the world for decades. However, the searches in concrete technology are remaining growing to meet particular properties related to its strength, durability, and sustainability issue. Thus, several types of concrete have been developed to enhance concrete performance. Most of the modern concrete types have to contain supplementary cementitious materials (SCMs) as a partial replacement of cement. These materials are either by-products of waste such as fly ash, slag, rice husk ash, and silica fume or from a geological resource like natural pozzolans and metakaolin (MK). Ideally, the utilization of SCMs will enhance the concrete performance, minimize environmental pollution and mitigate the drawbacks of cement production attributed to the highly $\mathrm{CO}_{2}$ emission. In general, MK's ultrafineness and high pozzolanic activity are exhibited a remarkable performance of concrete in terms of strength and durability. However, the filler effect, acceleration of cement hydration, and the pozzolanic reaction with calcium hydroxide $(\mathrm{CH})$ are the main factors influencing the performance of metakaolin as a cementitious material. Therefore, numerous researches have been undertaken on inclusion MK in concrete and mortar and production of (free-cement concrete) geopolymer concrete. This paper reviews some of previous native researches on effect of using Iraqi metakaolin as a pozzolanic material in different types of concrete. The standpoint of this review will guide the researchers on the importance of utilization of local MK and highlight the missing researches toward completing a comprehensive understanding of incorporation Iraqi-metakaolin in concrete technology.
\end{abstract}

Keywords: ordinary Portland cement, concrete, supplementary cementitious materials, Iraqimetakaolin.

*Corresponding author

Peer review under the responsibility of University of Baghdad.

https://doi.org/10.31026/j.eng.2021.08.06

2520-3339 () 2019 University of Baghdad. Production and hosting by Journal of Engineering.

This is an open access article under the CC BY4 license http://creativecommons.org/licenses/by/4.0/).

Article received:20/3/2021

Article accepted:5/6/2021

Article published:1/8/2021 


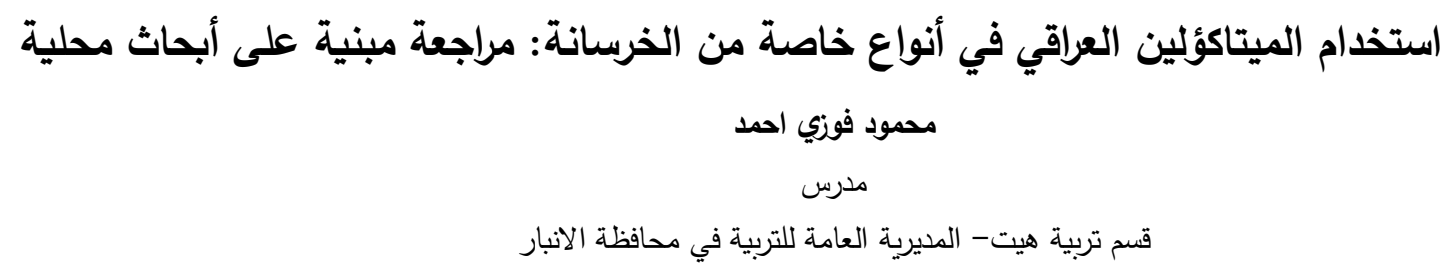

\section{الخلاصة}

تعتبر خرسانة السمنت البورتلاندي من مواد البناء والانثاء الأكثر استخدامًا في العالم منذ عقود. ومع ذلك، فإن البحوث في مجال تكنولوجيا الخرسانة لا تزال في تزايد مستمر لتلبية وتطوير بعض الخواص المعينة فيما يتعلق بالمقاومة والديمومة والاستدامة. لذلك تم تطوير عدة أنواع خاصة من الخرسانة لتحسين أداءها. تحتوي معظم أنواع الخرسانة الحديثة على مواد

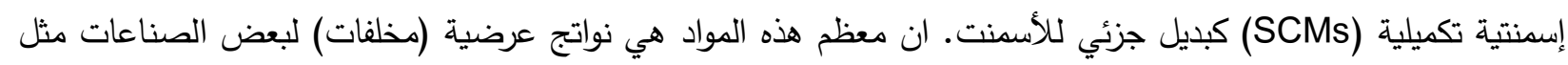
الرماد المتطاير ، وخبث الافران، ورماد قشور الرز , وابخرة السيليكا. كما يمكن ان تتنج هذه المواد من مصادر الارض هون الطبيعية

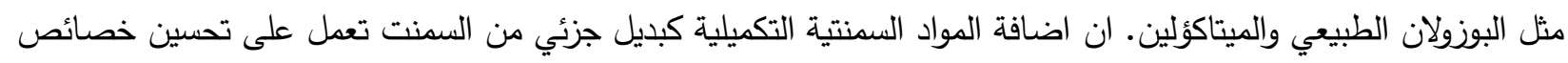
الخرسانة وديمومتها, وتقليل التلوث البيئي بالمخلفات الصلبة, كما تعمل على تقليل انبعاثات غاز ثنائي اوكسيد الكربون (CO



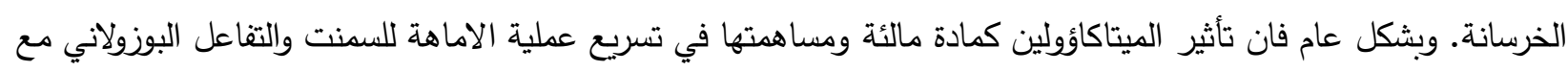

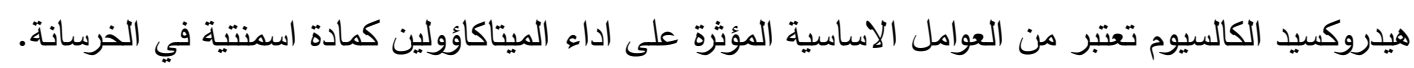
تم إجراء العديد من الأبحاث والدراسات حول استخدام الميتاكاؤولين (MK) في الخرسانة ومونة السمنت، بالإضافة إلى إنتاج الخرسانة الجيوبوليمرية (الخرسانة الخالية من السمنت) المعتمدة على الميتاكاؤولين. في مقالة المراجعة هذه سيتم استعراض

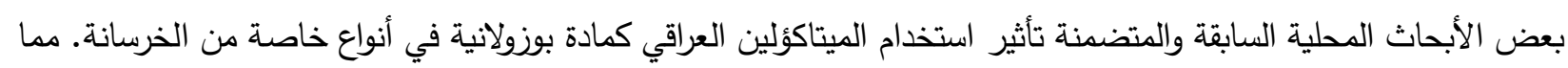
يسلط الضوء حول أهمية استخدام الميتاكاؤولين المحلي في الخرسانة، ويبين مسارات البحث المفقودة نحو استكمال فهم شامل لتأثير الميتاكؤلين العراقي في تكنولوجيا الخرسانة. الكلمات الرئيسية: السمنت البورتلاندي الاعتيادي, الخرسانة, المواد السمنتية التكميلية, الميتاكؤلين العراقي.

\section{INTRODUCTION}

Concrete is the most widely used construction material worldwide, and it has taken place as a second consumed substance after water (Duchesne, 2020). Therefore, the global demand for cement (the main constituent in the concrete matrix) has increased dramatically to reach up to 4.2 billion tons in 2019 (Lišovský, et al., 2021). Consequently, cement manufacturing is responsible for $5 \%-8 \%$ of the world's carbon dioxide $\left(\mathrm{CO}_{2}\right)$ emissions, causing a serious environmental greenhouse emissions and sustainability impact. One of the primary efforts for reducing the $\mathrm{CO}_{2}$ emission associated with concrete production is that the using of supplementary cementitious materials (SCMs) as partial replacement of ordinary Portland cement (OPC). However, utilization of SCMs not only minimize the OPC consumption and its related environmental pollution but also improves the fresh and hardened properties of concrete and enhancement its durability toward sustainable concrete industry (Juenger, et al., 2019), (Siddique and Khan, 2011), (Ramezanianpour, 2014). 
One type of (SCMs) is metakaolin (MK) which obtained by controlled heat treatment (calcination) of pure kaolin clay. The main reason for the inclusion of MK in cement based system is its pozzolanic activity, which is referred to the ability of silicates and aluminates in SCMs like (MK) to react with calcium hydroxide $(\mathrm{CH})$ from cement hydration to form secondary calcium-silicatehydrate (C-S-H) gel (Ramezanianpour, 2014), (Khatib, et al., 2018). This reaction will directly improve the interfacial transition zone (ITZ), and the microstructure becomes denser with less pores. As a result, the strength (mechanical properties) and durability of cementing composite will have been an enhancement. Kaolinite is the minerals clay that consists of an alternate crystalline layer structure of hydrated aluminum disilicate $\left(\mathrm{Al}_{2} \mathrm{O}_{3} \cdot 2 \mathrm{SiO}_{2} \cdot 2 \mathrm{H}_{2} \mathrm{O}\right)$, and this electrically- lamellar structure gives fine particle size, plate-like morphology, and softness soapy feel (Rashad, 2013). The geological formations of kaolin clay can be found in different regions worldwide like China, South America, North America, and Europe (Khatib, et al., 2018). There is an abundance of sedimentary (transported) kaolinite clay in Iraq, which have various names as; kaolin clay, ball clay, and kaolinitic claystone. Generally, most Iraqi kaolin clay deposits are recorded in the Western Desert of Anbar province, as shown in Fig. 1. The main exposed formations sectors containing kaolin clay are Ga'ara, Hussainiyat, and Amij Formations. The mineral composition of ball clay brought from (Duekhla deposit - Ga'ara Formation) is consist of (88\% kaolinite, $8 \%$ quartz, $0.4 \%$ organic matter and $3.6 \%$ others) depending on X-ray diffractometry (Tamar-Agha, et al., 2019), (Tamar-Agha, et al., 2020).

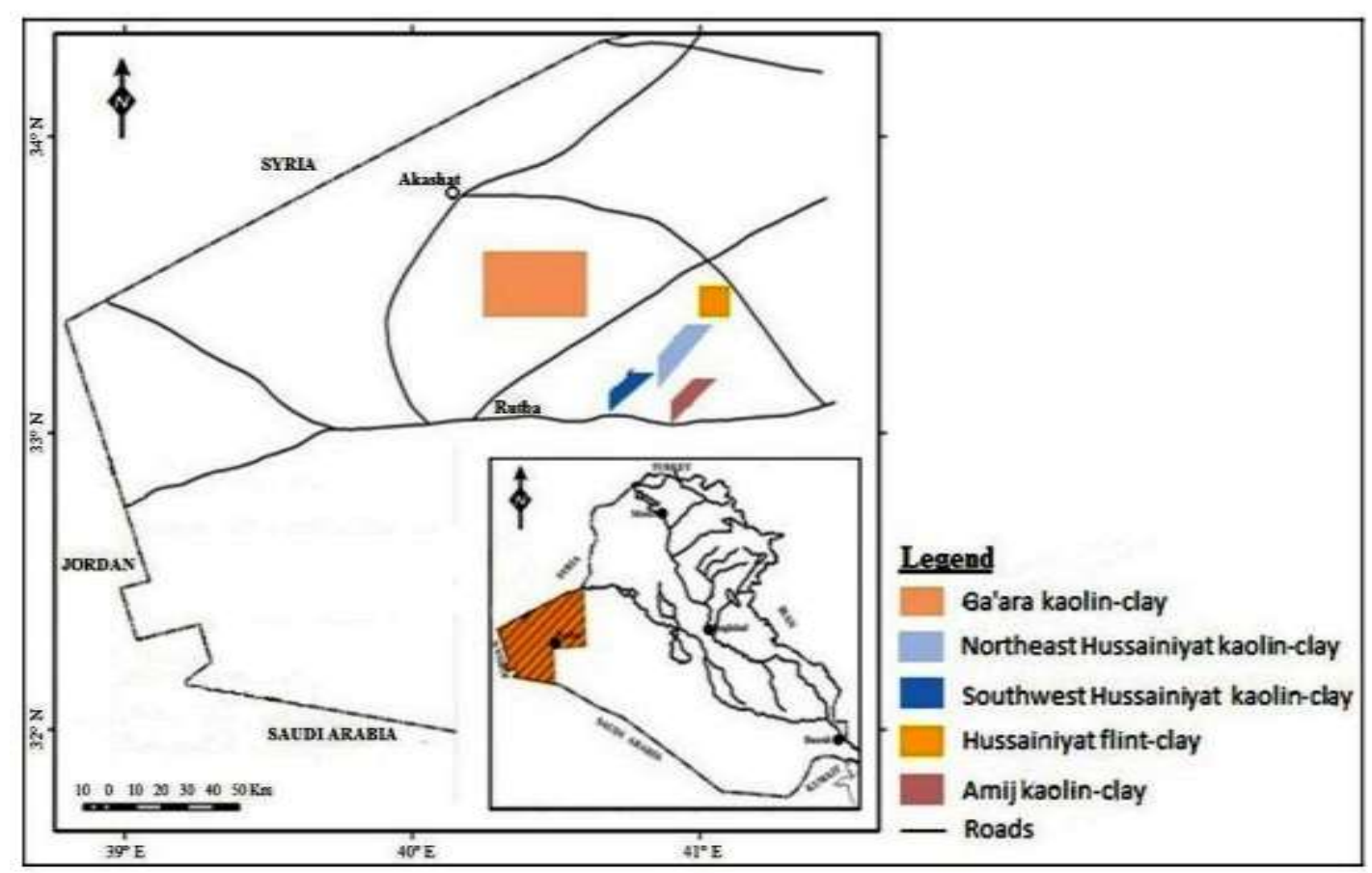

Figure 1. Location map of kaolin-clay deposits in the western desert of Iraq.

(Tamar-Agha, et al., 2019).

The plenty of kaolinite clay in Iraq's geological formation and the promising results of using MK in concrete have encouraged the native researchers to adopt the utilization of local MK as a pozzolanic addition for concrete and mortar. However, extensive research papers and academic thesis have been demonstrated using local metakaolin to produce different types of concrete. 
Therefore, this paper gives a review of the native researches that carried out on the effect of using Iraqi metakaolin as SCMs replacement of cement in concrete, or as a resource binder in the synthesis of geopolymer concrete.

\section{MANUFACTURING PROCESS AND CHEMICAL COMPOSITIONS OF IRAQI-MK}

Most of SCMs are by-products from industrial waste like fly ash (FA), ground granulated blast furnace slag (GGBS), and silica fume (SF), while some of them are pure as a natural pozzolan. However, metakaolin is produced by calcinating kaolin clay under carefully controlled heat treatment to temperatures of $600-900^{\circ} \mathrm{C}$ (Khatib, et al., 2018). The calcination temperature (thermal treatment) plays a crucial role in reactivating kaolinite toward production metakaolin as supplementary cementitious material by completing dehydroxylation as possible. However, during the burning or calcination process, kaolin would lose structural $\mathrm{OH}$ groups with more rearrangement of alumina and silica layers, leading to collapse and losing their long chains. Finally, the kaolinite flakes become more deformed and condensed into disordered, amorphous material known metakaolin. This product has a highly reactive transition phase, pozzolanic activity, and suitable for use as supplementary cementing materials in concrete applications (Khatib, et al., 2018), (Rashad, 2013), (Wang, et al., 2018).

The lower temperature is less effective in developing a reactive metakaolin. In contrast, the overheating causes the sintering of the kaolinite clay to form the dead burnt phase of non-reactive refractory named mullite (Ilić, et al., 2010). Most native researchers have taken the temperature of $700-750^{\circ} \mathrm{C}$ as an optimum calcination temperature of Iraqi metakaolin, depending on experimental work or previous studies. The study of (Ibrahem and Abdul Wahab, 2008) was carried out to optimization the calcination temperature and time of converting Iraqi kaolin to active metakaolin. The kaolinite clay has burned at five different temperatures $(550,600,650,700$, and 750) ${ }^{\circ} \mathrm{C}$ for one-half hour. The results indicated that the $700^{\circ} \mathrm{C}$ was the optimum calcination temperature with respect to the highest strength activity index (102\%). Moreover, the authors determined the best soaking time at $700^{\circ} \mathrm{C}$ by burning kaolinite for $0.5,1,1.5$, and 2 hours, then tested compressive strength of mortar with replacement of cement by $20 \% \mathrm{MK}$ for each tested time. The results show that the optimum calcination temperature of Iraqi kaolin clay is at $700^{\circ} \mathrm{C}$ for one hour. Not much different from these findings, (Sldozian, 2012) has found that among $(500,700$ and 900) ${ }^{\circ} \mathrm{C}$, the highest compressive strength of concrete mixtures containing $(5,10,15$ and 20) $\%$ of MK would be gained by calcination Iraq kaolinite clay at $700^{\circ} \mathrm{C}$ for $1 \mathrm{hr}$. The optimum replacement dosage was $5 \%$ which gain $30 \mathrm{MPa}$ of compressive strength at 28 -day. In spite of the mineralogical of MK is like silica fume, which composed essentially of amorphous aluminosilicate (Si-Al-O) phase. Still, the chemical composition of SF contains more than $85 \% \mathrm{SiO}_{2}$ by mass vs. $50 \%$ for MK.

Consequently, MK is taking a second level after SF in pozzolan hierarchy as active pozzolan material (Nawy, 2008). Generally, the main chemical components of Iraqi MK are the silica and alumina oxides (over $80 \%$ by mass) with less quantity of ferric oxide. Table 1 summarizes the calcination temperature and chemical composition of researchers that used Iraqi metakaolin. 
Table 1. Calcination temperature and chemical composition of Iraqi-MK used in previous studies.

\begin{tabular}{|c|c|c|c|c|c|c|c|c|c|c|c|}
\hline \multirow[b]{2}{*}{$\begin{array}{l}\mathbb{d} \\
\stackrel{\sim}{*}\end{array}$} & \multirow{2}{*}{ 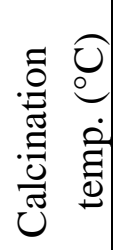 } & \multirow[b]{2}{*}{  } & \multicolumn{9}{|c|}{ Chemical composition $(\%)$} \\
\hline & & & $\overbrace{n=1}^{N}$ & 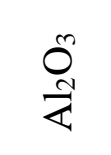 & $\begin{array}{l}\bigcup_{\mathbb{N}} \\
\text { II }\end{array}$ & ְ. & $\sum_{\sum}^{\infty}$ & 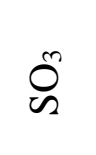 & $\begin{array}{l}0 \\
\text { Z̃ } \\
\text { Z }\end{array}$ & $\begin{array}{l}\underset{\sim}{\Delta} \\
\underline{\Delta}\end{array}$ & ت্. \\
\hline  & 700 & 1 & 53.0 & 32.0 & 0.9 & 1.10 & 1.08 & I & I & I & 13 \\
\hline 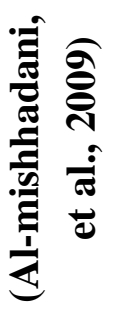 & 700 & / & 51.32 & 32.90 & 1.10 & 1.70 & 0.10 & 0.18 & 0.23 & 0.43 & 6.47 \\
\hline 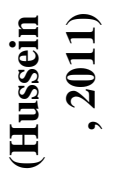 & 700 & 1 & 51.34 & 33.40 & 2.30 & 3.0 & 0.17 & 0.15 & / & / & 7.8 \\
\hline  & 700 & 1 & 55.24 & 37.1 & 1.47 & 1.12 & 0.13 & 0.07 & 0.15 & I & 3.59 \\
\hline 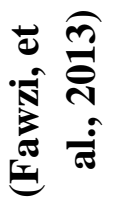 & 700 & 1 & 52.38 & 37.31 & 1.21 & 1.68 & 0.30 & / & / & 0.44 & I \\
\hline
\end{tabular}


$\begin{array}{lllll}\text { Number } 8 & \text { Volume } 27 & \text { August } 2021 & \text { Journal of Engineering }\end{array}$

\begin{tabular}{|c|c|c|c|c|c|c|c|c|c|c|c|}
\hline 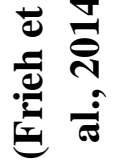 & 700 & 1 & 55.22 & 32.38 & 1.54 & 2.24 & 0.41 & 2.85 & I & I & 3.35 \\
\hline 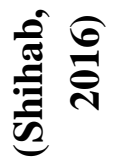 & 700 & 1 & 57.45 & 36.83 & 1.41 & 1.12 & 0.03 & 0.08 & 0.50 & I & 1.54 \\
\hline 远 & 750 & I & 51.70 & 32.90 & 1.10 & 1.70 & 0.10 & 0.18 & 0.51 & I & 8.64 \\
\hline  & 800 & 2 & 53.60 & 36.80 & 1.97 & 0.78 & 0.32 & 0.17 & 0.43 & 0.84 & 4.83 \\
\hline 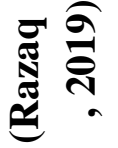 & 700 & 1 & 54.88 & 36.29 & 1.40 & 0.38 & 0.21 & 0.21 & 0.66 & I & 2.47 \\
\hline 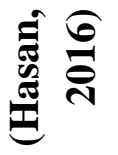 & 700 & 1 & 51.59 & 38.11 & 1.82 & 0.45 & 0.23 & 0.14 & 0.11 & 0.43 & 6.12 \\
\hline 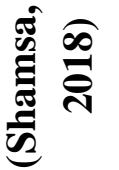 & 700 & 2 & 56.77 & 30.85 & 2.48 & 0.58 & 0.59 & l & I & I & l \\
\hline 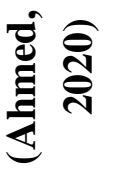 & 700 & 2 & 54.20 & 39.0 & 0.92 & 1.37 & 0.15 & 0.45 & 0.22 & 0.27 & 0.71 \\
\hline
\end{tabular}

According to (ASTM C618-17), the calcination natural clay can be categorized as pozzolanic material if the summation of the three main oxides $\left(\mathrm{SiO}_{2}, \mathrm{Al}_{2} \mathrm{O}_{3}\right.$, and $\left.\mathrm{Fe}_{2} \mathrm{O}_{3}\right)$ is equal to or higher than $70 \%$. From Table 1, it can be concluded that all the Iraqi metakaolin can be classified as pozzolanic for use in concrete. Moreover, the electronic scanning microscopy (SEM) revealed that the Iraqi metakaolin particles are platy-form, angular, and have a lamellar structure, as shown in Fig. 2. 

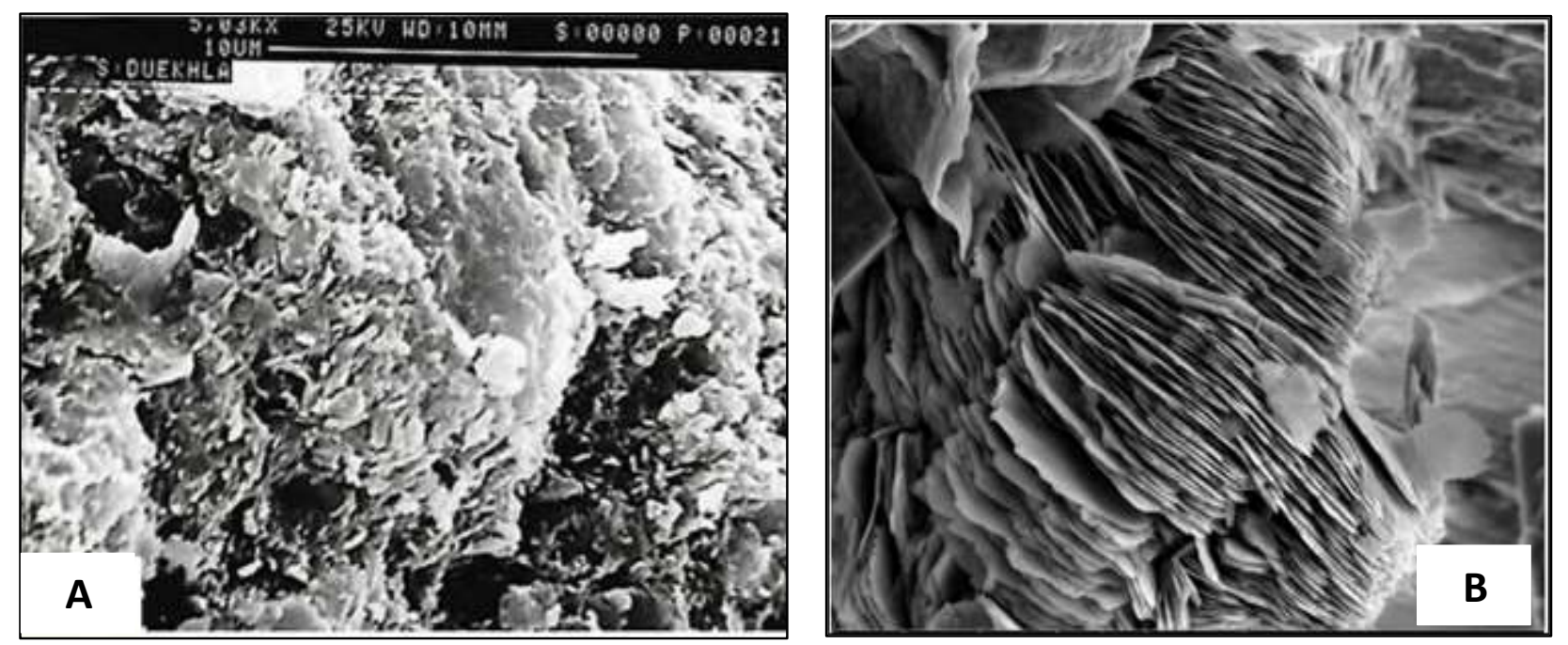

Figure 2. SEM image of Iraqi MK. (view-A) (Tamar-Agha,et al., 2020)

(view-B) (Shamsa, 2018).

\section{SPECIAL TYPES OF CONCRETE INVOLVING IRAQI-METAKAOLIN}

In the last decades, several types of concrete have been developed for meeting the desirable properties under specific circumstances such as workability, strength, and durability. On the other hand, a new generation of concrete has been modified in some ways for sustainable development in concrete technology and considered its strong performance. This section briefly reviews and discusses the influence of using local metakaolin on some properties of self-compacting concrete (SCC), high-performance concrete (HPC), and other miscellaneous types and the production of geopolymer concrete based on Iraqi metakaolin as the main precursor.

\subsection{Self-compacting concrete}

Self-compacting concrete is considered as one of the modern and developing concrete, that have ability of flowing and passing under its weight without segregation (Sirivivatnanon et al., 2003). Many local researchers have investigated the effect of utilization Iraqi metakaolin on the characteristics of SCC, as discussed in the following sections:

\subsubsection{Fresh properties}

Generally, the inclusion of MK seems to have an adverse effect on the workability of concrete (Siddique and Khan, 2011), (Ramezanianpour, 2014), and that related to the high fineness of MK and its plate-like particles. The relationship between fresh properties of SCC and Iraqi-MK content has been widely investigated by local studies (Hadi and Habeeb, 2011), (Owaid, et al., 2018), (Razaq, et al., 2019), (Alwash, 2013), and (Hameed, 2019). Generally, all authors found that the inclusion of MK as cement replacement would minimize the workability of SCC in relation to the slump flow diameter, the ratio of L-box, and the time of the V-funnel test. Fig. 3 shows the variation of workability tests results of SCC with different MK contents from previous studies. It can be observed that without adequate dosage of superplasticizer, replacement of $15 \% \mathrm{MK}$ can be reduced the slump flow diameter and L-Box ratio up to $6 \%$ and $10 \%$, respectively. In 
comparison, the time of V-funnel increased by 50\% compared to the control SCC mix. as in the research of (Razaq et al., 2019).

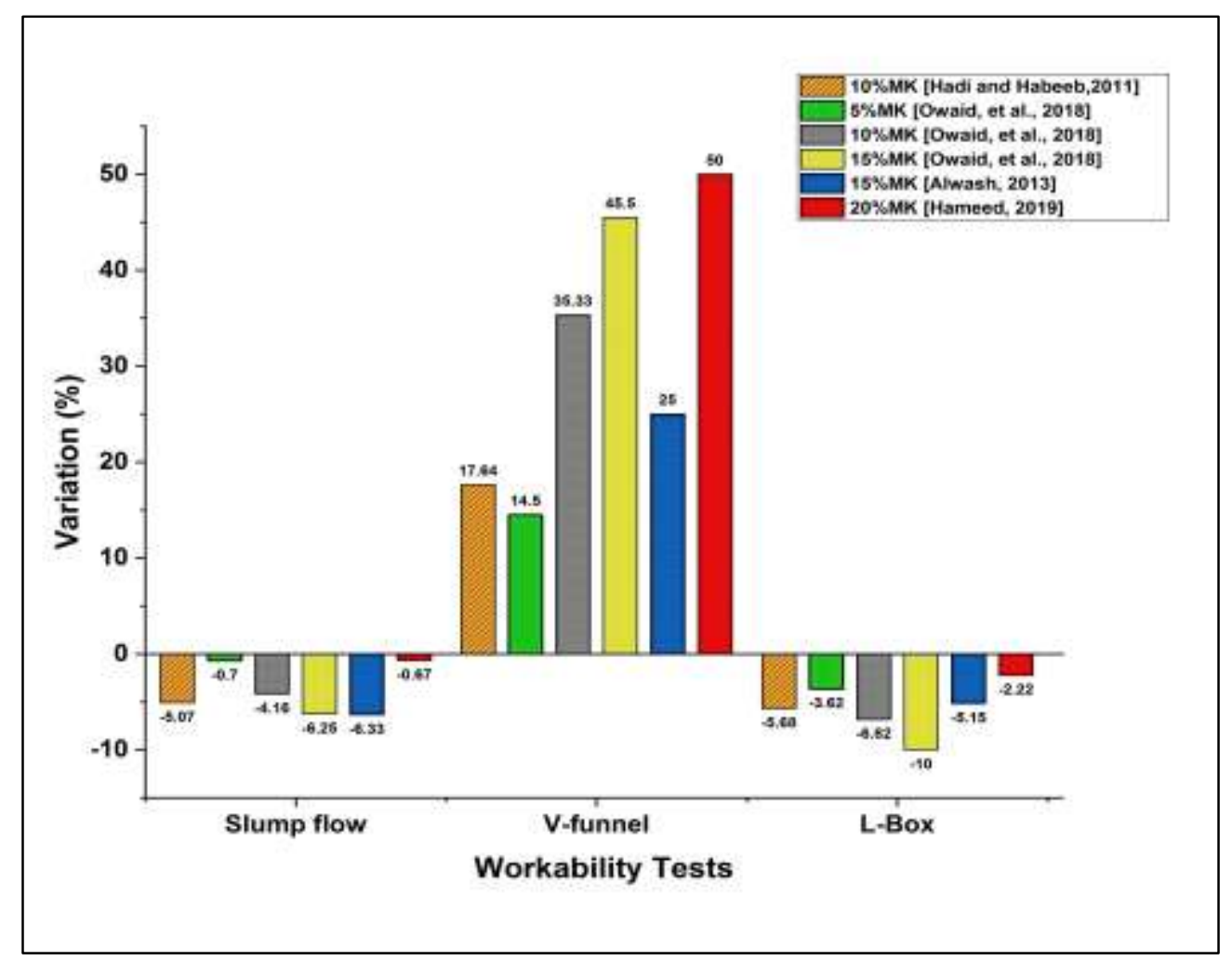

Figure 3. The relative percentage for the effect of MK content on the workability of SCC.

\subsubsection{Mechanical properties}

The mechanical properties of concrete provide an essential quantification of concrete strength. The compressive, flexural, tensile strength and static modulus of elasticity are the main variables for the structural design process and determining the concrete quality and durability properties (Pillay et al., 2020). The adding of Iraqi metakaolin as a partial content of the binder in SCC significantly affects its mechanical properties. Table 2 summarizes some of the previous local researches on mechanical properties of SCC containing different amounts of Iraqi-MK. It can be observed that the substitution of ordinary Portland cement with Iraqi metakaolin has improved the mechanical properties of SCC. However, both studies (Hadi and Habeeb, 2011) (Razaq, et al., 2019) showed that the replacement level of $10 \% \mathrm{MK}$ attaining the optimum strength performance. This enhancement in mechanical properties attributed to the pozzolanic activity of MK to forming additional gel (C-S-H), as mentioned in the introduction section. Also, MK displays filler materials that can fill the voids and pores present in the microstructure and, therefore, reduce the porosity within the concrete matrix. (Siddique and Khan, 2011) . 
Table 2. Mechanical properties of SCC with different contents of Iraqi-MK.

\begin{tabular}{|c|c|c|c|}
\hline Reference & $\begin{array}{c}\text { MK } \\
\text { content }\end{array}$ & $\begin{array}{l}\text { Strength } \\
\text { properties } \\
\text { studied }\end{array}$ & Findings ( in comparison with reference mix) \\
\hline \multirow{3}{*}{$\begin{array}{c}\text { (Hadi and } \\
\text { Habeeb, } \\
\text { 2011) }\end{array}$} & \multirow{3}{*}{$10 \%$} & Compressive & $\begin{array}{l}\text { (+) by } 14.2 \%, 11.4 \% \text { and } 14.5 \% \text { at } 28,90 \text { and } 180 \\
\text { days, respectively. }\end{array}$ \\
\hline & & Splitting & $\begin{array}{l}\text { (+) by } 5.2 \%, 10.3 \% \text { and } 31.3 \% \text { at } 28,90 \text { and } 180 \text { days, } \\
\text { respectively. }\end{array}$ \\
\hline & & $\begin{array}{l}\text { Static modulus of } \\
\text { elasticity }\end{array}$ & $\begin{array}{l}\text { (+) by } 11.2 \%, 13 \% \text { and } 9.6 \% \text { at } 28,90 \text { and } 180 \text { days, } \\
\text { respectively. }\end{array}$ \\
\hline \multirow{3}{*}{$\begin{array}{c}\text { (Owaid, } \\
\text { et al., 2018) }\end{array}$} & $5 \%$ & \multirow{3}{*}{ Compressive } & (+) by $3.9 \%$ and $2.1 \%$ at 28 and 90 days, respectively. \\
\hline & $10 \%$ & & $\begin{array}{l}\text { (+) by } 11.1 \% \text {, and } 8.8 \% \text { at } 28 \text { and } 90 \text { days, } \\
\text { respectively. }\end{array}$ \\
\hline & $15 \%$ & & (+) by $8.7 \%$, and $4.9 \%$ at 28 and 90 days, respectively. \\
\hline \multirow{6}{*}{$\begin{array}{c}\text { (Razaq } \\
\text { et al., 2019) }\end{array}$} & \multirow{2}{*}{$5 \%$} & Compressive & $\begin{array}{l}\text { (+) by } 11.8 \% \text {, and } 11.1 \% \text { at } 28 \text { and } 90 \text { days, } \\
\text { respectively. }\end{array}$ \\
\hline & & Splitting & $\begin{array}{l}\text { (+) by } 15.1 \% \text {, and } 13.5 \% \text { at } 28 \text { and } 90 \text { days, } \\
\text { respectively. }\end{array}$ \\
\hline & \multirow{2}{*}{$10 \%$} & Compressive & $\begin{array}{l}\text { (+) by } 17.6 \% \text {, and } 15.7 \% \text { at } 28 \text { and } 90 \text { days, } \\
\text { respectively. }\end{array}$ \\
\hline & & Splitting & $\begin{array}{l}\text { (+) by } 24.2 \% \text {, and } 21.6 \% \text { at } 28 \text { and } 90 \text { days, } \\
\text { respectively. }\end{array}$ \\
\hline & \multirow[t]{2}{*}{$15 \%$} & Compressive & $\begin{array}{l}(+) \text { by } 2.17 \% \text {, and } 7.5 \% \text { at } 28 \text { and } 90 \text { days, } \\
\text { respectively. }\end{array}$ \\
\hline & & Splitting & (+) by $9 \%$, and $13.5 \%$ at 28 and 90 days, respectively. \\
\hline \multirow{3}{*}{ (Alwash, } & \multirow{3}{*}{$15 \%$} & Compressive & $\begin{array}{l}(+) \text { by } 8.4 \%, 9.5 \% \text { and } 13.4 \% \text { at } 7,28 \text { and } 90 \text { days, } \\
\text { respectively. }\end{array}$ \\
\hline & & Flexural & $\begin{array}{l}(+) \text { by } 8.6 \% \text {, and } 16.5 \% \text { at } 28 \text { and } 90 \text { days, } \\
\text { respectively. }\end{array}$ \\
\hline & & $\begin{array}{l}\text { Static modulus of } \\
\text { elasticity }\end{array}$ & $\begin{array}{l}\text { (+) by } 2.1 \%, 9.5 \% \text { and } 4.1 \% \text { at } 28 \text { and } 60 \text { days, } \\
\text { respectively. }\end{array}$ \\
\hline
\end{tabular}

\subsubsection{Durability properties}

The durability of concrete is defined as the capability of concrete components to withstand the severe exposure conditions for which it has been designed throughout the structure's service life (Mehta and Monteiro, 2006). The durability properties of SCC contain Some native researchers have conducted Iraqi metakaolin.

(Hadi and Habeeb, 2011) have investigated the durability performance of SCC that exposed to (sulfates-chlorides) solution at a concentration similar to that of soil and groundwater in the south part of Iraq. Four mixes of SCC have been prepared with mineral admixture: control SCC mix (0\% admixture), $10 \% \mathrm{MH}, 30 \% \mathrm{LSP}$ (limestone powder), and blended of $10 \% \mathrm{MK}+30 \% \mathrm{LSP}$. The mechanical properties and the changes in weight and length have been determined after subimmersion in (Cl-1 + SO4-2) saline till 180 days for each mix. The authors found that compressive and tensile strengths of exposed SCC-10\%MK would increase continuously without any deterioration. Also, it has provided the minimum reduction in mechanical properties, weight loss, and length changes compared to the control mix and other mixes. 
(Ammash, et al., 2013) evaluated the effect of internal sulfates in fine aggregate on some mechanical properties of SCC containing blended $10 \% \mathrm{MK}$ plus limestone powder. Natural gypsum was added as a partial replacement for the sand weight at four dosages as; $(0.37,0.5,1$, $1.5) \%$. All SCC specimens were tested for compressive and splitting strength at 28, 56, and 90 days of curing. The results indicated that the optimum gypsum content was $0.5 \%$ relative to the higher strength, and then the mechanical properties decreased with an increase of sulfate content. The inclusion of $10 \% \mathrm{MK}$ as cement replacement has a positive effect in reducing the loss of strength (compressive and tensile) at all ages.

\subsection{High Performance Concrete}

High performance concrete (HPC) is concrete that has been designed to attain mechanical properties, durability, or constructability that exceeds those of normal concrete. ACI concrete terminology has been defined (HPC) as concrete meeting special combinations of performance and uniformity requirements. Thus, the production of (HPC) is required more attention in mixing, placing, and curing practices (Sirivivatnanon et al., 2003). Typically, utilization of SCMs (mainly silica fume) as a part of cement and noticeable superplasticizer dosage are essential requirements in HPC production (Aïtcin, 1998). Despite utilizing silica fume as a main and fabulous cementitious material in making HPC, but some national researchers have focused on producing HPC based on using Iraqi activated kaolinite clay as SCMs. Generally, the inclusion of local MK as a partial replacement of cement has produced HPC with a mean of compressive strength ranged (60-70) MPa at the age of 28-day, and this depending on a high content of cement (more than 500 $\mathrm{kg}$ ) and sufficient amount of high range water reducer. Fig. 4 shows some values of compressive strength of HPC for previous studies. (Shihab, 2016), (Aday, 2018) (Mohammed, 2012), (Algalawi and Hassooni, 2016).



Figure 4. Compressive strength of HPC with different contents of Iraqi - MK. 
(Al-janabi, 2007) has used two types of local pozzolanic materials in the synthesis of HPC, where the cement was replaced either by $8 \%$ of high reactive metakaolin (HRM) or $10 \%$ fly ash. Another study about the effect of using HRM on the properties of high performance steel fiber reinforced concrete was prepared by (Mohammed, 2012). The dosages 5\%, 10\%, and 15\% of HRM have been used as a cement replacement with steel fiber at $2 \%$ of volume concrete. Also, (Shihab, 2016) has evaluated the chloride ion penetration of HPC containing 8\% HRM and reinforced with $2 \%$ of steel fiber.

Moreover, (Al-galawi and Hassooni, 2016) have investigated the durability properties of two mixes of HPC, ones containing 10\% of local HRM, and the other with silica fume at $8 \%$ and $10 \%$ for cement weight. The main findings and results based on previous studies regarding the mechanical and durability properties of HPC containing local MK are summarized in Table 3.

Table 3. Summary of HPC behavior containing local Metakaolin.

\begin{tabular}{|c|c|c|c|c|}
\hline Reference & $\begin{array}{c}\mathrm{MK} \\
\text { content }\end{array}$ & $\begin{array}{c}\text { Investigated } \\
\text { properties }\end{array}$ & Type of Exposure & Main findings \\
\hline 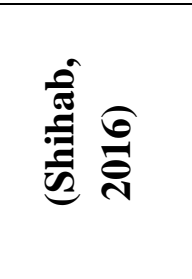 & $8 \%$ & Durability & $\begin{array}{l}\text { External chloride } \\
\text { ion solution up to } \\
300 \text { days }\end{array}$ & $\begin{array}{l}\text { The inclusion of } 8 \% \mathrm{MK} \text { enhanced } \\
\text { the chloride resistance, as reducing } \\
\text { chloride penetration, electrical } \\
\text { conductivity, and the ratio of }(\mathrm{Cl} \\
\text { free/Cl total). }\end{array}$ \\
\hline \multirow{3}{*}{ 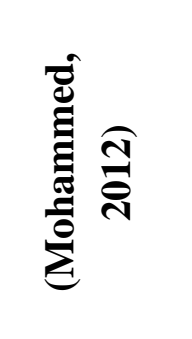 } & $5 \%$ & \multirow{3}{*}{ Mechanical } & \multirow{3}{*}{ l } & \multirow{3}{*}{$\begin{array}{l}\text { Improved compressive, flexural, } \\
\text { and splitting strength observed in } \\
\text { the sample of HPC containing MK; } \\
\text { and optimum MK content is } 10 \% \\
\text { respect to the highest compressive } \\
\text { strength. }\end{array}$} \\
\hline & $10 \%$ & & & \\
\hline & $15 \%$ & & & \\
\hline  & $10 \%$ & Durability & $\begin{array}{l}\text { Internal sulfate } \\
\text { attack by adding } \\
\text { natural gypsum as } \\
\text { a replacement of } \\
\text { sand weight ( } 1,2 \text {, } \\
\text { and } 3) \% \text { up to } \\
120 \text { days. }\end{array}$ & $\begin{array}{l}\text { HPC with } 10 \% \text { HRM showed better } \\
\text { resistance to internal sulfate attack } \\
\text { than those of } 8 \% \text { and } 10 \% \text { SF at all } \\
\text { ages of the test. }\end{array}$ \\
\hline 萑 & $8 \%$ & Durability & $\begin{array}{l}\text { Internal sulfate } \\
\text { attack by adding } \\
\text { natural gypsum as } \\
\text { a replacement of } \\
\text { sand weight up to } \\
270 \text { days. }\end{array}$ & $\begin{array}{l}8 \% \mathrm{MK} \text { minimized the negative } \\
\text { impact of internal sulfate attack on } \\
\text { losing compressive and flexural } \\
\text { strength of HPC. }\end{array}$ \\
\hline
\end{tabular}




\subsection{Miscellaneous Types}

Recently, Iraqi research has been expanded in concrete technology that involves the utilization of local metakaolin. (Fawzi, et al., 2013) have developed lightweight concrete based on porcelinate aggregate with four percentages of $\operatorname{MK}(5,10,15$, and 20) \% as cement replacement. Compared with the reference mix ( $0 \% \mathrm{MK})$, all lightweight concrete mixtures containing MK have a higher fresh and dry density and a significant improvement in mechanical properties. The authors indicated that the $10 \%$ of $\mathrm{MK}$ is the optimum replacement level as the compressive strength of the control mix increased from 20 MPa to 47.1 MPa, whereas the dry unit weight $\left(1806 \mathrm{~kg} / \mathrm{m}^{3}\right)$ stay in the range of lightweight concrete, which can be used as lightweight structural concrete in many civil engineering applications.

On the other hand, (Frieh et al., 2014) investigated using a high fraction of Iraqi metakaolin (10\% up to $70 \%$ ) instead of ordinary Portland cement to produce a high volume-metakaolin concrete a solution in mass concrete products. The results indicated that the workability decrease with an increase of MK content, and it should increase the dosage of superplasticizer to get the same workability. Moreover, the optimum replacement dosage was $20 \%$ of MK, which provided the highest compressive, flexural, splitting strengths and static modulus of elasticity, and after this dosage, a noticeable reduction of mechanical properties has been recognized, especially for mixes with $60 \%$ and $70 \%$ MK content.

Another study was carried out by (Awad et al., 2018) to evaluate the effect of the inclusion of three percentages $(5 \%, 7 \%$, and $10 \%)$ of MK on the performance of reactive powder concrete exposed to internal sulphate attack. For each MK replacement dosage, fine natural aggregate with high sulphate content $\left(\mathrm{SO}_{3}=0.75 \%\right)$ was used to prepared reactive powder concrete specimens. All specimens have been tested for compressive, flexural, and splitting tensile strengths at 7 up to 120 days. The results revealed that the mechanical properties increased with an increase of MK content, whereas $10 \% \mathrm{MK}$ content was the optimum replacement dosage with the highest strengths at all ages. On the other hand, regardless of the MK replacement level, the mixtures' contented high dosage of sulfate in fine aggregate has shown lower mechanical properties compared to control mixes at all test ages. Also, the mix of $10 \% \mathrm{MK}$ and sulphate sand content has shown the lowest reduction in strengths among other mixes, whereas the reduction of compressive strength for $10 \%$ MK-samples reached $1.95 \%$ at 120 days vs. $3.1 \%$ and $2.35 \%$ for mixes with $5 \%$ and $7 \%$ MK content, respectively.

\subsection{Geopolymer Concrete}

Geopolymer concrete is represented as the next generation of conventional concrete to be accepted for using in construction and building sector due to its durable properties and high strength associated with more environmentally benefits which eliminate the production of ordinary Portland cement and subsequently, minimizing the $\mathrm{CO}_{2}$ emissions universally (Amran et al., 2021),(Imtiaz et al., 2020). Geopolymer is synthesized by interacting aluminosilicate precursors such as fly ash, metakaolin, slag, or silica fume with an alkaline solution of either $\mathrm{NaOH}$ or $\mathrm{KOH}$ and $\mathrm{Na}_{2} \mathrm{SiO}_{3}$ or $\mathrm{K}_{2} \mathrm{SiO}_{3}$ (Mahmoodi et al., 2021). The environmental advantages, besides to proven excellent strength and durability performance of geopolymer concrete, have encouraged the national researchers to deal with Iraqi metakaolin as the main source of silica and alumina toward the production of sustainable geopolymer concrete.

Basil et al. (Al-Shathr et al., 2015), and (Al-Shether, et al.,) have presented an extensive investigation of optimization mix design and curing system of geopolymer concrete based on local Iraqi metakaolin. The main parameters were silicate to hydroxide ratio of alkaline solution, 
fineness of metakaolin, and curing regime. At the same time, the mix proportions have been fixed at $(400,720$, and 1100$) \mathrm{kg} / \mathrm{m}^{3}$ for metakaolin, fine aggregate, and coarse aggregate, respectively. It has been reported that the compressive strength of geopolymer concrete increased with a high fineness of metakaolin, and the optimum curing system was under sunlight in the summer season at a temperature $(32-48){ }^{\circ} \mathrm{C}$.

In the same manner, (Shamsa et al., 2018) have studied the effect of concentration and ratio of ( $\left.\mathrm{NaOH}: \mathrm{Na}_{2} \mathrm{SiO}_{3}\right)$ of alkaline solution and amount of binder on the strength of MK-based geopolymer concrete. The curing regime was carried by placing the molds after casting inside an electric oven for 16 hours, and then de-molded the specimens and continuously the heat treatment at $45 \pm 5^{\circ} \mathrm{C}$ for 48 hours. In the other part of their investigation, Mohammed et al. (Shamsa et al., 2019) have evaluated the durability performance against 300 cycles of freezing and thawing for MK-based geopolymer concrete. Compared with fly ash geopolymer concrete and ground granulate blast furnace slag geopolymer concrete, the specimens of MK-based geopolymer concrete would provide less resistance to freezing and thawing at $68 \%$ durability factor, reaching $77 \%$ and $81 \%$ for FA and GGBFS samples, respectively.

(Alserai et al., 2019) studied the effect of iron filling on the mechanical properties of sustainable MK-based geopolymer concrete. Two series of geopolymer concrete have been produced, once with natural coarse aggregate and the other with recycled concrete coarse aggregate. For each group, the iron filling was added at $0.5 \%, 0.75 \%$, and $1 \%$. Generally, the mixtures with natural aggregate have exhibited higher mechanical properties in comparison with those of recycled aggregate, while the increase of iron filling would increase all the mechanical properties.

On the other hand, (Ahmed et al., 2019) conducted a series of trials to optimize the mix proportions of MK-based geopolymer concrete related to the highest strength and more sustainable-sufficient curing regime. However, the maximum obtained compressive strength reached up to $40 \mathrm{MPa}$ at 7 days with 14 molarity of the alkaline solution and curing for 5 hours at $60^{\circ} \mathrm{C}$ followed with exposure to sunlight in summer season at degree $(35-49)^{\circ} \mathrm{C}$.

Another advantage of using metakaolin-based geopolymer concrete is that it allows reusing and recycling solid waste materials as constituents within concrete matrix. (Ahmed et al., 2019) and (Khalil et al., 2019) have been evaluated the possibility of utilization waste clay brick as a binder and as a coarse aggregate in the synthesis of MK-geopolymer concrete, respectively. The MK has substituted with waste clay brick powder at $10 \%, 15 \%$, and $20 \%$ by weight, while the natural coarse aggregate has replaced with crushed clay brick aggregate at volume levels $10 \%, 20 \%$, and $30 \%$. In spite, the inclusion of waste brick in each feature has impacted negatively upon compressive strength. Still, the obtained strengths ranged between 20.5 to $41.7 \mathrm{MPa}$ at the age of 28 days, thus providing a more sustainable concrete that can be used in structural applications. The main mix proportions and influence parameters of production Iraqi-MK geopolymer concrete by various researchers are summarized in Table 4. 
Table 4. The observed parameters of production geopolymer concrete based on Iraqi MK

\begin{tabular}{|c|c|c|c|c|}
\hline \multirow[b]{2}{*}{ Items } & \multicolumn{4}{|c|}{ References } \\
\hline & $\begin{array}{c}\text { (Al-Shathr et } \\
\text { al., 2015) }\end{array}$ & $\begin{array}{c}\text { (Shamsa et al., } \\
\text { 2018) }\end{array}$ & $\begin{array}{c}\text { (Alserai et al., } \\
\text { 2019) }\end{array}$ & $\begin{array}{c}\text { (Ahmed et al., } \\
\text { 2019) }\end{array}$ \\
\hline MK content $(\mathrm{kg})$ & 400 & 300 & 400 & 415 \\
\hline $\begin{array}{l}\text { Mix proportions } \\
\text { (MK:Sand:Gravel) }\end{array}$ & $(1: 1.8: 2.75)$ & $(1: 2.16: 4)$ & $(1: 1.8: 2.75)$ & $(1: 1.14: 2.98)$ \\
\hline $\begin{array}{l}\text { Fineness of } \mathrm{MK} \\
\left(\mathrm{m}^{2} / \mathrm{gm}\right)\end{array}$ & 23.0 & 17.25 & l & 14.3 \\
\hline $\begin{array}{l}\text { Molarity of } \\
\text { solution }\end{array}$ & 10 & 12 & 14 & 14 \\
\hline $\mathrm{NaOH}: \mathrm{Na}_{2} \mathrm{SiO}_{3}$ & $1: 3.5$ & I & $1: 3.5$ & $1: 2$ \\
\hline $\begin{array}{l}\text { Curing method of } \\
\text { specimens }\end{array}$ & $\begin{array}{l}\text { Exposed to } \\
\text { sunlight in } \\
\text { summer }\end{array}$ & $\begin{array}{l}\text { Inside oven at } \\
45 \pm 5^{\circ} \mathrm{C} \text { as } \\
\text { follow: } \\
\text { With mold for } \\
16 \mathrm{hr} \text {, } \\
\text { After de-molded } \\
\text { for } 20 \mathrm{hr} \text {. }\end{array}$ & $\begin{array}{l}\text { Under sunlight } \\
\text { at }(27-30){ }^{\circ} \mathrm{C}\end{array}$ & $\begin{array}{l}\text { Inside oven at } \\
60{ }^{\circ} \mathrm{C} \text { for } 4-5 \mathrm{hr} \text {, } \\
\text { then under } \\
\text { sunlight at }(35- \\
49){ }^{\circ} \mathrm{C} \text { in } \\
\text { summer }\end{array}$ \\
\hline $\begin{array}{l}\text { Compressive } \\
\text { strength (MPa) }\end{array}$ & 27.53@7 days & $\begin{array}{l}\text { 24.95@7 days } \\
34.44 @ 28 \text { days }\end{array}$ & $30.8 @ 28$ days & $\begin{array}{r}41.4 @ 7 \text { days } \\
44.03 @ 28 \text { days }\end{array}$ \\
\hline
\end{tabular}

\section{CONCLUSIONS}

This review paper summarizes some of the national researches regarding the effect of using Iraqi activated kaolinite clay (metakaolin) as a partial cement replacement in different types of concrete. This study included the geographical information of kaolinite deposits in Iraq, chemical compositions, and thermal optimization treatment of metakaolin. Additionally, the fresh, hardened properties and some durability aspects have been investigated for particular types of concrete-like self-compacting concrete, high-performance concrete, and geopolymer concrete. The main findings notes across various studies of Iraqi researchers can be described in the following:

1 - It is possible to produce (metakaolin) throw thermal activation of Iraqi kaolin clay at an optimum temperature of $700{ }^{\circ} \mathrm{C}$ for $1-2 \mathrm{hr}$.

2- The chemical composition analysis and strength activity index has indicated that Iraqi metakaolin can be classified as natural pozzolan type N according to ASTM C-618 for using as cementitious or pozzolanic materials in concrete.

3- The workability of self-compacting concrete has been adversely affected by the inclusion of MK as a partial replacement of cement. Therefore, more attention should be considered to using an optimum dosage of MK content in the SCC mixture.

4- Incorporation of $10 \%-15 \%$ of Iraqi metakaolin as SCMs would provide the ability to produce HPC with compressive strength up to $60-70 \mathrm{MPa}$, with superior durability performance. 
5- There is a significant withstanding against aggressive environments like sulfate, chloride attacks, and external crude oil exposure of special concrete types containing MK.

6- The high volume fraction of Iraqi-MK within cement composite is an appropriate technique for a mass concrete application. In contrast, the highest strength gained by $20 \%$ MK content and mixes of $30-50 \%$ MK content have a moderate strength for structural purposes, while the dosage of $70 \% \mathrm{MK}$ is unacceptable for replacement cement in concrete.

7- A scientifically proven Iraqi metakaolin can be used as a main precursor in synthesizing geopolymer concrete with great strength properties depending on accurate mix proportions, concentration of alkali solution, and sufficient curing regime.

Summarily, there was a common agreement across all previous national studies that the utilization of Iraqi metakaolin has shown a beneficial impact on developing special types of concrete. This also proves the feasibility of $\mathrm{MK}$ as an alternate binder of cement for enhancing sustainability in concrete technology. Therefore, further investigations are required to determine the characteristics and serviceability of structural applications based on special concrete types containing MK.

\section{REFERENCES}

- Aday, L. A., 2018. Effects of reactivity metakaolin on properties of high strength concrete, International Journal of Engineering and Technology (UAE), 7(4), pp. 2132-2136. DOI: 10.14419/ijet.v7i4.13584.

- Ahmed, M. F., 2020. Properties of Geopolymer Concrete Containing Waste Materials, Ph.D. thesis, University of Technology, Baghdad, Iraq.

- Aïtcin, P.C., 1998. High performance concrete. CRC press.

- Al-galawi, N.M. and Hassooni, S.A., 2016. The Effect of Cement and Admixture Types on the Resistance of High Performance Concrete to Internal Sulphate Attack. Journal of Engineering, 22(2), pp.74-92.

- Al-Janabi, T.H., 2007. Behavior of High Performance Concrete Exposed to Internal Sulphate Attack, M. Sc. Thesis, University of Technology, Iraq.

- Alserai, S.J., Alsaraj, W.K. and Abass, Z.W., 2018. Effect of iron filings on the mechanical properties of different types of sustainable concrete. The Open Civil Engineering Journal, 12(1).

- Al-Shathr, B.S., Al-Attar, T.S. and Hasan, Z.A., 2015. Optimization of Geopolymer Concrete Based on Local Iraqi Metakaolin. In The 2nd International Conference of Buildings, Construction and Environmental Engineering (pp. 97-100).

- Al-Shathr, B.S., Al-Attar, T.S. and Hasan, Z.A., 2016. Effect of curing system on metakaolin based geopolymer concrete. Journal of Babylon University, 24(3), pp.569-576. 
- Alwash, J. J. H., 2013. Self Compacting Concrete Incorporating Rice Husk Ash And Metakaolin. Al-Qadisiyah Journal for Engineering Sciences, 6(2), 124-138.

- Ammash, H. K., Al-Baghdadi, H. M. and Al-Salim, N. H. A., 2013. Effect of Sulfates in Fine Aggregate on Some Properties of Self Compacting Concrete Incorporating High Reactive Metakaoline, Al-Qadisiyah Journal for Engineering Sciences, 6(4), pp. 426-438.

- Amran, M., Debbarma, S. and Ozbakkaloglu, T., 2021. Fly ash-based eco-friendly geopolymer concrete: A critical review of the long-term durability properties. Construction and Building Materials, 270, p.121857.

- ASTM C618-17a, 2017. Standard Specification for Coal Fly Ash and Raw or Calcined Natural Pozzolan for Use in Concrete, ASTM International, West Conshohocken, PA, 2017, DOI: $10.1520 / \mathrm{C} 0618-17 \mathrm{~A}$.

- Awad, H.K., Aboud, R.K. and Mohammed, S.D., 2018. Influence of percentage replacement of metakaolin on different concrete types exposed to internal sulphate attack. International Journal of Engineering \& Technology, 7(4.20), pp.514-519.

- Duchesne, J., 2020. Alternative supplementary cementitious materials for sustainable concrete structures: a review on characterization and properties, Waste and Biomass Valorization. Springer Netherlands, pp.1-18. DOI: 10.1007/s12649-020-01068-4.

- Fawzi M. N., Aziz K. I., and Hama M. S., 2013. Effect of Metakaolin on Properties of Lightweight Porcelinate Aggregate Concrete, Journal of Engineering, 19(4), pp. 439-452.

- Frieh, K. J., Abbas, W. A., and Hamid, M. M., 2014. Some Properties of Concrete Containing High Fraction Volume of Metakaolin, Eng. \& Tech. Journal, 32(1), pp. 230-248.

- Hadi, A. M., and Habeeb, G. M., 2011. The Effect of Sulfates in Groundwater on Some Mechanical Properties of Self-Compacting Concrete. Journal of Kerbala University, 9(1).

- Hameed, D. H., 2019. Effect of Reactive Metakaolin Prepared by Thermal Shock on Some Mechanical Properties of Self-Compacting Concrete. Journal of the University of Babylon for Engineering Sciences, 27(2), 287-299.

- Hasan, Z. A., 2016. Manufacturing and Studying Properties of Geopolymer Concrete Produced by Using Local Materials, Ph. D. thesis, Universtiy of Technology, Baghdad, Iraq.

- Hussein, Z. M. A., 2011. The Effect of Accelerated Curing on Compressive Strength of Selfcompacting Concrete. Journal of Engineering and Sustainable Development, 15(4).

- Ibrahem, A. M., and Abdul Wahab, K. A., 2008. Effect of temperature on the pozzolanic properties of Metakaolin produced from Iraqi kaolin clay. AL-Fatih Journal, 4(32). 
- Ilić, B. R., Mitrović, A. A., and Miličić, L. R., 2010. Thermal treatment of kaolin clay to obtain metakaolin. Hemijska Industrija, 64(4), 351-356.

- Imtiaz, L., Rehman, S.K.U., Ali Memon, S., Khizar Khan, M., and Faisal Javed, M., 2020. A Review of Recent Developments and Advances in Eco-Friendly Geopolymer Concrete. Applied Sciences, 10(21), p.7838.

- Juenger, M. C. G., Snellings, R., and Bernal, S. A., 2019. Supplementary cementitious materials: New sources, characterization, and performance insights, Cement and Concrete Research. Elsevier, 122(February), pp. 257-273. DOI: 10.1016/j.cemconres.2019.05.008.

- Khalil, W.I., Frayyeh, Q.J. and Ahmed, M.F., 2019. Evaluation of sustainable metakaolingeopolymer concrete with crushed waste clay brick. In IOP Conference Series: Materials Science and Engineering (Vol. 518, No. 2, p. 022053). IOP Publishing.

- Khatib, J. M. B., Baalbaki, O. and Elkordi, A., 2018. Metakaolin, Chapter 15 in Waste and Supplementary Cementitious Materials in Concrete, Waste and Supplementary Cementitious Materials in Concrete, (December), pp. 493-511.

- Lišovský, M., Kocáb, D., Sikorová, V., Vymazal, T. and Hrabová, K., 2021. Future of concrete structures. SPECIAL CONCRETE AND COMPOSITES 2020: 17th International Conference.

- Mahmoodi, O., Siad, H., Lachemi, M., Dadsetan, S. and Sahmaran, M., 2021. Development of normal and very high strength geopolymer binders based on concrete waste at ambient environment. Journal of Cleaner Production, 279, p.123436.

- Mehta, P.K. and Monteiro, P.J., 2006. Concrete: microstructure, properties, and materials. McGraw-Hill Education.

- Mohammed, R.Y., 2012. Properties of high performance steel fiber reinforced concrete containing high reactivity metakaolin. Journal of techniques, 25(1).

- Nawy, E.G., 2008. Concrete construction engineering handbook. CRC Press, Taylor \& Francis Group, LLC.

- Owaid, H. M., Ghali, Z. A. S., and Ali Dawood, S. A., 2018. Compressive strength, ultrasonic pulse velocity and transport properties of self-compacting high performance concrete made with Iraqi metakaolin, International Journal of Civil Engineering and Technology, 9(7), pp. 31-44.

- Pillay, D. L., Olalusi, O. B., Awoyera, P. O., Rondon, C., Echeverría, A. M., and Kolawole, J. T., 2020. A Review of the Engineering Properties of Metakaolin Based Concrete: Towards Combatting Chloride Attack in Coastal/Marine Structures, Advances in Civil Engineering, DOI: $10.1155 / 2020 / 8880974$. 
- Ramezanianpour, A. A., 2014. Cement Replacement Materials: Fly Ash. Available at: http://link.springer.com/10.1007/978-3-642-36721-2.

- Rashad, A. M., 2013. Metakaolin as cementitious material: History, scours, production and composition-A comprehensive overview, Construction and Building Materials, 41, pp. 303318. DOI: 10.1016/j.conbuildmat.2012.12.001.

- Razaq, W. A., Freih, Q. J., Al-Obaidy S. J., 2019. The Effect of Using Multi Types of Mineral Admixtures on Some Properties of Lightweight Self-Compacting Concrete, Engineering and Technology Journal, 37(1 Part C), pp. 186-194.

- Salih, S. A., Salih, M. A. and Al Foadi, W. K., 2009. Mechanical Properties of High Performance Concrete Re-tempered in Different Ambient Temperatures, The Iraqi Journal For Mechanical And Material Engineering, Special Issue (D.).

- Shamsa, M. H., April 2018. Performance Evaluation of Geopolymer Concrete According to ACI 318-14 Exposure Categories and Classes, Ph. D. thesis, University of Technology, Baghdad, Iraq.

- Shamsa, M.H., Al-Shathr, B.S. and Al-Attar, T.S., 2018. Effect of pozoolanic materials on compressive strength of geopolymer concrete. Kufa Journal of Engineering, 9(3).

- Shamsa, M.H., Al-Shathr, B.S. and Al-Attar, T.S., 2019. Performance of Geopolymer Concrete Exposed to Freezing and Thawing Cycles. Engineering and Technology Journal, 37(3 Part A).

- Shihab, A. M., 2016. Effect of Using Metakaolin on Chloride Ion Penetration in High Performance Steel Fiber Reinforced Concrete, Journal of Babylon University/Engineering Sciences, 24(1), pp. 191-202.

- Siddique, R., and Khan, M. I., 2011. Supplementary cementing materials. Springer Science \& Business Media.

- Sirivivatnanon, V., Tam, C. T., and Ho, D. W. S., 2003. Special Concrete and Applications, Chen, W. F., \& Liew, J. R. (Eds.), The civil engineering handbook., United States of America, CRC Press.

- Sldozian, R. J. A, 2004. Study the effect of fired kaolin on some properties of concrete. MSc thesis, University of Technology, Baghdad, Iraq.

- Tamar-Agha, M. Y., Mahdi, M. A., and Ibrahim, A. A., 2019. The Kaolin Clay Deposits In The Western Desert of Iraq: An overview. Iraqi Bulletin of Geology and Mining, (8), 147-173.

- Tamar-Agha, M. Y., Mustafa, M. M. and Ibrahim, A. A. A., 2020. Characterization and Potential Industrial Utilization of the Permian Kaolin Clay Deposits, Ga'Ara Area, Western Iraq, Iraqi Bulletin of Geology and Mining, 16(1), pp. 105-126. Available at: http://ibgmiq.org/. 
- Wang, F., Kovler, K., Provis, J. L., Buchwald, A., Cyr, M., Patapy, C., Sideris, K., 2018. Metakaolin. In Properties of Fresh and Hardened Concrete Containing Supplementary Cementitious Materials (pp. 153-179). Springer, Cham. 